\title{
Factors of Public Self-Disclosure Via Instagram Stories
}

\author{
Shella Eunice Purmiasa', Desi Yoanita ${ }^{2}$, Daniel Budiana ${ }^{3}$ \\ 1, Communication Science, Petra Christian University, Indonesia \\ ${ }^{2}$ Communication Science, Petra Christian University, Indonesia \\ ${ }^{3}$ Communication Science, Petra Christian University, Indonesia \\ Corresponding Author's Email : dy-nita@petra.ac.id
}

\begin{abstract}
Openness is an important factor in relationship maintenance. However, excessive self-disclosure can jeopardize the privacy or security of one's own identity. Therefore, we need to manage the boundaries between private or public information. This privacy management explained by Sandra Petronio in the Communication Privacy Management Theory (CPM). Before the rise of social media, someone usually conveys private information face to face to others who have personal closeness. Yet, social media changes the old manner. Nowadays, someone could share their personal stories (public self-disclosure) to people they haven't know well. This research was conducted to determine the factors that cause Instagram stories users in five largest cities in Indonesia doing public selfdisclosure. Researchers used seven indicators of CPM theory namely: perceived control, privacy awareness, privacy concern, privacy invasion experience, privacy risk, interaction, and tie strength, adapted from Ampong et al. The result shows that users of Instagram stories in Indonesia strongly consider privacy concern factor. However, users do not consider privacy invasion experience factor too much. In addition, researchers found that gender and educational background showed differences of consideration among respondents. Overall, this research shows that Instagram stories users in Indonesia have been managing their personal information according to CPM theory.
\end{abstract}

Keywords: Communication Privacy Management, Instagram story users, public self-disclosure

\section{INTRODUCTION}

Openness is important in maintaining relationships with fellow human beings. Openness is what drives a person to make disclosures about self-identity to others which is called self-disclosure. However, there is a risk if someone cannot control the act of self-disclosure (DeVito, 2005). In other words, excessive selfdisclosure can jeopardize the privacy or security of one's own identity, so we need to manage the boundaries between things that are public and private.

This privacy management is explained by Sandra Petronio in the Communication Private Management Theory (CPM). Petronio (2002) says that privacy is important to us because it allows us to feel separated from others. Because there are risks that can arise from opening up the wrong person or saying 
too much about ourselves (in West \& Turner, 2014, p.253). He also argues that there are characteristics of privacy rules, where the development of a relationship is guided by the criteria for a person's decision to disclose or cover up his private information (West \& Turner, 2014). One of the criteria that is the focus of this research is the risk-benefit criteria or "cost \& rewards". Where a person must weigh the risks as well as what benefits will be obtained if he makes disclosures about personal information.

In line with the growth of information and communication technology, privacy is not only needed in establishing relationships face-to-face, but when we deal online through new media. Green in The Internet: An Introduction to New Media 2nd Edition, states that one of the definitions of the internet in the context of new media is blogs and social networking sites (SNS), such as Facebook, YouTube, Instagram, Snapchat, and so on. In social networking sites, anyone can pick up any content about personal life, eventually leading to a culture of sharing and selfdisclosure on excessive social media (Cross in Nasrullah, 2015).

Speaking of self-disclosure on social networking sites (SNS), the classic notion of self-disclosure is the process of revealing the "hidden self" part with others directly, apparently in conflict with the notion of self-disclosure in SNS. Because, according to Bazaroya \& Choi, "public self-disclosure on SNS is not in accordance with the classical understanding of self-disclosure, because its behavior is limited to a closed interaction system, and most of its interactions are dyadic" (Bazaroya \& Choi, 2014, p.637). Whereas basically self-disclosure on SNS can be shared in dyadic or selective processes with a certain group of recipients (for example via Direct Message on Instagram or Messenger on Facebook), many of the users who prefer to share status or content publicly with the entire network of "friends" or its followers (Gilbert \& Karahalios, 2009 in Bazaroya \& Choi, 2014).

Users who share their personal identities or daily activities on SNS are referred to as someone who is doing public self-disclosure. The purpose of users doing public self-disclosure is to maintain social ties, build social capital through new connections, seek feedback, to maintain social relationships, and as entertainment (Ampong et al., 2018). Basically, the activities shared by users on SNS are very diverse and broad because of the freedom given by SNS. So that makes users become aware of privacy rights, as well as certain restrictions that already have their own policies.

There are factors that cause a person to do public self-disclosure on various social networking sites that can be specific predictors in seeing privacy issues in the online environment. Factors adapted from Ampong et al. 'S journal are considered as consideration of risk - benefit criteria (in CPM theory) that would be obtained if SNS users wanted to do public self - disclosure. These factors consist of perceived control, privacy awareness, privacy concern, privacy invasion experience and privacy risk which are considered as consideration of the risks that will be obtained. While the interaction factor and tie strength are considered as consideration of the benefits to be gained.

One of the fastest growing social networking sites is Instagram. Indonesia is one of the countries with the most Instagram users among developing countries 
(Goenawan, 2017). According to Statista, as of January 2019 Instagram stories users in Indonesia had reached 62 million people (Statista, 2019). In addition, the increased use of applications that have existed since 2010 occurred because it was driven by one of the emergence of new features namely Instagram stories (Bohang, 2018). Sri Widowati (Country Director of Facebook Indonesia) revealed that users in Indonesia upload almost twice as much Instagram story content than the global average (Jeko, 2017).

APAC's Instagram Brand Development Lead, Paul Webster, revealed that Instagrammers Indonesia is the majority of young people, educated and established (Mailanto, 2016). When viewed by age, most Instagram users in Indonesia as of October 2018 are in the $18-24$ years age range with $39.4 \%$ or $15,474,163$ people (NapoleonCat, 2018). So based on these facts, researchers made Indonesian people aged 18-24 years become the population of this study. But by limiting only the people of the cities of Jakarta, Surabaya, Bandung, Medan and Semarang to become the "Top 5 Cities" in Indonesia per 2017 (Gilbert, 2017 - www.worldatlas.com).

Previous research on the use of social media on self-disclosure was conducted by Adrian Mailoor in 2017 with the title "The Effect of the Use of Snapchat Social Media on Self-Disclosure of Communication Studies Students at the Faculty of Social and Political Sciences at Sam Ratulangi University". In this study, researchers want to see the same problem from the perspective of user privacy when self-disclosure on social networking sites with a greater number of active users such as Instagram stories. So researchers can find out "What are the factors that cause users of Instagram stories to do public self-disclosure?"

\section{LITERATURE REVIEW}

\section{Communication Privacy Management (CPM)}

The main concern in the Communication Privacy Management Theory is the management of tensions between openness or privacy, between making yourself part of being public and being private. Openness is not only an individual decision, but is managed by a relationship contract that includes "shared costs and rewards". The point is that once we reveal personal information to other people, then that information becomes a shared property between us and others. So that information must be coordinated together about what may be disclosed and what is not (Morrisan, 2013).

Petronio sees that managing boundaries between private and public areas is a process that uses rules (Morrisan, 2013). If in a face-to-face relationship, negotiation between the two parties is needed regarding what rules may be violated or not. Neither is the context of online relationships in the digital world. However, this privacy regulation is only implemented between social networking site platforms and the user. Users must weigh the costs and benefits felt from selfdisclosure, as well as perceived costs including loss of privacy that may have some adverse effects in the digital and physical world (Ampong, et al. 2018). So it takes a policy from the user to control what you want disclosed. 


\section{Self-Disclosure on Social Networking Sites (Public Self-Disclosure)}

Initially, self-disclosure is only carried out during the face-to-face process between two or more people. Where self-capturing is a process of disclosing information about ourselves to others (Bungin, 2006). Altman \& Dalmas Taylor put forward in the theory of social penetration that when a person does self-disclosure, then he will pass some degree of self-disclosure. The degree of self-disclosure is described as an onion with a degree of breadth and depth. The level of breadth shows the topic areas or parts of a person's life such as tastes, studies (studies), worldview (worldview) and romance (dating). While the depth level is described as a layer of onions. At the surface level the exchange of biographical information (the outermost layer) may take place easily at the first meeting. But the layers of the onion skin will be harder and more tightly packed when approaching the innermost layer (Griffin, 2012).

Along with advances in communication \& information technology, selfdisclosure is not only done face-to-face, but through conventional media and new media such as social networking sites. According to Bazaroya \& Choi "public selfdisclosure on SNS is not in accordance with the classic understanding of selfdisclosure, because its behavior is limited to a closed interaction system, and most of its interactions are dyadic (two-way communication)" (Bazaroya \& Choi, 2014, p. 637). Jiang, Bazorva \& Hancock $(2011,2013)$ say that this dyadic model moves from offline disclosure to online dyadic interactions (in Ampong et al., 2018).

Ampong et al., (2018) stated in the Journal of "Examining Self-Disclosure on Social Networking Sites: A Flow Theory and Privacy Perspective" that researchers have observed if people are still more open on platforms such as SNS, where there is a sense of anonymity and freedom to express oneself, which may not be expressed in direct or face-to-face conversation. The reason someone does self-disclosure on SNS (public self-disclosure) is to maintain social ties, build social capital through new connections, seek feedback, to maintain social relationships, and as entertainment (Ampong et al., 2018 ).

\section{Factors Causing Public Self-Disclosure}

There are factors that cause someone to do public self-disclosure on various social networking sites. In this study, researchers adapted the indicators regarding the factors causing SNS users in performing public self-disclosure owned by Ampong et al. (2018). It's just one of the factors namely Focused Attention contained in the journal Ampong et al. not used as an indicator. Because these factors are not based on Communication Privacy Management theory, but Flow Theory which is a psychological theory. Then the researchers found a match between the literature review of Ampong et al. with CPM theory, that these factors have the potential for loss and profit (cost \& rewards) that are considered by someone to do public self-disclosure. Explanation of the factors will be divided into parts of costs and rewards to explain what factors are the risks and benefits, but these factors remain unified (only 1 variable). These factors can be described as follows: 
- Cost

1. Perceived Control (PCL), to find out how control is felt by users in using SNS through privacy settings.

2. Privacy Awareness (PA), to find out the user's privacy awareness about privacy options available on SNS.

3. Privacy Concerns (PC), to find out how users worry about seeing privacy issues and whether users have processed information before being shared on SNS.

4. Privacy Invasion Experience (PIE), to find out what actions users take when experiencing an invasion of privacy.

5. Privacy Risk (PR), to find out the user's awareness of their privacy security risks.

- Rewards

6. Interaction (FINT), to find out the interaction between respondents and other SNS users. Interaction is one of the benefits obtained when doing public self-disclosure.

7. Tie Strength (TS), to determine the strength of interpersonal bonds that are formed through SNS.

\section{METHODOLOGY}

The number of samples from this study were 400 respondents with the criteria of the people of Jakarta, Surabaya, Bandung, Medan, and Semarang aged 18-24 years who used personal accounts and had uploaded content on Instagram stories at least once a month, regarding personal information or daily activities. The type of sampling used is non probability sampling with a purposive sampling technique, where this technique includes people selected on the basis of certain criteria from the researcher. Respondents of this study were obtained by sending the link of online questionnaire via direct messages to many Instagram accounts. In addition, the researchers also asked friends to help spread the links of online questionnaire.

The data measurement method used in this study is a Likert scale used to measure the attitude of respondents in responding to questions or problems in a particular research (Sarwono, 2012). Likert scale can be described as follows: strongly disagree (STS) with a score of 1, disagree (TS) with a score of 2, agree (S) with a score of 3 , strongly agree (SS) with a score of 4 . In this study, researchers did not enter alternative responses "neutral", because these responses give a double meaning and result in respondents who are hesitant tend to choose responses "neutral". Thus causing a lot of data loss (Soehartono, 2008, p.77). 
RESULTS AND DISCUSSION

Table 1. Reliability Test

\begin{tabular}{|c|c|c|c|}
\hline Indicator & $\begin{array}{c}\text { Cronbach's } \\
\text { Alpha }\end{array}$ & (r) table & Notes \\
\hline Perceived Control (PCL) & 0,812 & 0,6 & Reliable \\
\hline Privacy Awareness (PA) & 0,890 & 0,6 & Reliable \\
\hline Privacy Concern (PC) & 0,865 & 0,6 & Reliable \\
\hline Privacy Invasion Experience (PIE) & 0,813 & 0,6 & Reliable \\
\hline Privacy Risk (PR) & 0,836 & 0,6 & Reliable \\
\hline Interaction (FINT) & 0,864 & 0,6 & Reliable \\
\hline Tie Strength (TS) & 0,840 & 0,6 & Reliable \\
\hline Total & 0,822 & 0,6 & Reliable \\
\hline
\end{tabular}

Table 2. Data of Socio-Demographic

\begin{tabular}{|c|c|c|c|}
\hline Variables & Description & Frequency & Percent \\
\hline \multirow[t]{2}{*}{ Gender } & Male & 262 & 34.5 \\
\hline & Female & 138 & 65.5 \\
\hline \multirow[t]{2}{*}{ Age } & 18 to 21 & 167 & 41.75 \\
\hline & 22 to 24 & 233 & 58.25 \\
\hline \multirow[t]{7}{*}{ Education Background } & Elementary School & 0 & 0 \\
\hline & Junior High School & 10 & 2.5 \\
\hline & High School & 231 & 57.8 \\
\hline & Associate & 9 & 2.3 \\
\hline & Bachelor & 145 & 36.3 \\
\hline & Master & 3 & 0.8 \\
\hline & $\begin{array}{l}\text { Professional } \\
\text { Education }\end{array}$ & 2 & 0.5 \\
\hline \multirow[t]{5}{*}{ Residence of Respondent } & Jakarta & 233 & 58.25 \\
\hline & Surabaya & 56 & 14 \\
\hline & Bandung & 54 & 13.5 \\
\hline & Medan & 32 & 8 \\
\hline & Semarang & 25 & 6.25 \\
\hline \multirow[t]{5}{*}{ Frequency of Disclosure } & Several times a day & 145 & 36.3 \\
\hline & Once a day & 73 & 18.3 \\
\hline & Once a week & 58 & 14.5 \\
\hline & Bi-weekly & 61 & 15.3 \\
\hline & Once a month & 63 & 15.8 \\
\hline
\end{tabular}


Table 3. Factors of Public Self-Disclosure Via Instagram Stories

\begin{tabular}{|c|c|c|c|c|c|}
\hline Indicator & Items & Mean & Mean & SD & A \\
\hline \multirow[t]{3}{*}{$\begin{array}{l}\text { Perceived } \\
\text { Control } \\
(\mathrm{PCL})\end{array}$} & $\begin{array}{l}\text { I want to share information about } \\
\text { myself on Instagram stories } \\
\text { because I am in control of the IG } \\
\text { account, not someone else or the } \\
\text { admin. }\end{array}$ & 3,22 & \multirow{3}{*}{3.21} & \multirow{3}{*}{0.66275} & \multirow{3}{*}{0,812} \\
\hline & $\begin{array}{l}\text { I want to share information about } \\
\text { myself on Instagram stories } \\
\text { because Instagram's privacy } \\
\text { settings allow me to control the } \\
\text { information. }\end{array}$ & 3,23 & & & \\
\hline & $\begin{array}{l}\text { I want to share information about } \\
\text { myself on Instagram stories } \\
\text { because I feel I can control who } \\
\text { can see that information. }\end{array}$ & 3,21 & & & \\
\hline \multirow[t]{6}{*}{$\begin{array}{l}\text { Privacy } \\
\text { Awareness } \\
\text { (PA) }\end{array}$} & $\begin{array}{l}\text { I want to share information about } \\
\text { myself on Instagram stories } \\
\text { because I already read the terms \& } \\
\text { data policy at the beginning of } \\
\text { creating an Instagram account. }\end{array}$ & 3,06 & \multirow{6}{*}{3.17} & \multirow{6}{*}{0.61150} & \multirow{6}{*}{0,890} \\
\hline & $\begin{array}{l}\text { I want to share information about } \\
\text { myself on Instagram stories } \\
\text { because Instagram terms \& data } \\
\text { policies are easy to understand. }\end{array}$ & 3,03 & & & \\
\hline & $\begin{array}{l}\text { I want to share information about } \\
\text { myself on Instagram stories } \\
\text { because Instagram's privacy } \\
\text { settings are easy to use. }\end{array}$ & 3,32 & & & \\
\hline & $\begin{array}{l}\text { I want to share information about } \\
\text { myself on Instagram stories } \\
\text { because I understand all of } \\
\text { Instagram's privacy settings. }\end{array}$ & 3,22 & & & \\
\hline & $\begin{array}{l}\text { I want to share information about } \\
\text { myself on Instagram stories } \\
\text { because I know all the appropriate } \\
\text { actions to ensure my privacy on } \\
\text { Instagram is guaranteed. }\end{array}$ & 3,21 & & & \\
\hline & $\begin{array}{l}\text { I want to share information about } \\
\text { myself on Instagram stories } \\
\text { because I am aware of my privacy } \\
\text { and responsibility rights on } \\
\text { Instagram. }\end{array}$ & 3,21 & & & \\
\hline \multirow[t]{3}{*}{$\begin{array}{l}\text { Privacy } \\
\text { Concern } \\
(\mathrm{PC})\end{array}$} & $\begin{array}{l}\text { I selected information that I would } \\
\text { share on Instagram stories for fear } \\
\text { that the information could be } \\
\text { misused. }\end{array}$ & 3,42 & \multirow{3}{*}{3.29} & \multirow{3}{*}{0.67350} & \multirow{3}{*}{0,865} \\
\hline & $\begin{array}{l}\text { I selected information that I would } \\
\text { share on Instagram stories for fear } \\
\text { someone might find my personal } \\
\text { information. }\end{array}$ & 3,23 & & & \\
\hline & $\begin{array}{l}\text { I selected information that I would } \\
\text { share on Instagram stories for fear }\end{array}$ & 3,25 & & & \\
\hline
\end{tabular}




\begin{tabular}{|c|c|c|c|c|c|}
\hline & $\begin{array}{l}\text { of what other people might do with } \\
\text { it. } \\
\text { I selected information that I would } \\
\text { share on Instagram stories because } \\
\text { the information could be used in a } \\
\text { way that I did not expect. }\end{array}$ & 3,27 & & & \\
\hline \multirow{2}{*}{$\begin{array}{l}\text { Privacy } \\
\text { Invasion } \\
\text { Experience } \\
\text { (PIE) }\end{array}$} & $\begin{array}{l}\text { I reduce the activity of sharing my } \\
\text { personal information on Instagram } \\
\text { stories because I often fall victim } \\
\text { to privacy violations }\end{array}$ & 2,19 & \multirow[b]{2}{*}{2.34} & \multirow[b]{2}{*}{0.91341} & \multirow[b]{2}{*}{0,813} \\
\hline & $\begin{array}{l}\text { I reduced my sharing of personal } \\
\text { information on Instagram stories } \\
\text { because of hearing or reading } \\
\text { about the potential misuse of user } \\
\text { information over the past year }\end{array}$ & 2,51 & & & \\
\hline \multirow[t]{3}{*}{$\begin{array}{l}\text { Privacy } \\
\text { Risk (PR) }\end{array}$} & $\begin{array}{l}\text { I reduce the activity of sharing } \\
\text { personal information on Instagram } \\
\text { stories because I have a very high } \\
\text { chance to lose control of that } \\
\text { information. }\end{array}$ & 2,62 & \multirow{3}{*}{2.60} & \multirow{3}{*}{0.85216} & \multirow{3}{*}{0,836} \\
\hline & $\begin{array}{l}\text { By registering and using } \\
\text { Instagram, my personal } \\
\text { information will be used without } \\
\text { my knowledge, thus making me } \\
\text { reduce sharing activities on } \\
\text { Instagram stories. }\end{array}$ & 2,59 & & & \\
\hline & $\begin{array}{l}\text { I reduce the activity of sharing } \\
\text { personal information on Instagram } \\
\text { stories because hackers (hackers) } \\
\text { might control my account if I open } \\
\text { myself on Instagram stories. }\end{array}$ & 2,61 & & & \\
\hline \multirow[t]{5}{*}{$\begin{array}{l}\text { Interaction } \\
\text { (FINT) }\end{array}$} & $\begin{array}{l}\text { I want to continue to share my } \\
\text { personal information, because } \\
\text { Instagram stories provide } \\
\text { opportunities to participate in } \\
\text { communication using groups or } \\
\text { online communities. }\end{array}$ & 2,80 & \multirow{4}{*}{2.93} & \multirow{4}{*}{0.70204} & \multirow{4}{*}{0,864} \\
\hline & $\begin{array}{l}\text { I want to continue to share my } \\
\text { personal information, because } \\
\text { Instagram stories support the } \\
\text { function of making connections } \\
\text { with other users. }\end{array}$ & 2,96 & & & \\
\hline & $\begin{array}{l}\text { I want to continue to share my } \\
\text { personal information, because } \\
\text { Instagram stories help me share } \\
\text { thoughts or feelings quickly. }\end{array}$ & 2,88 & & & \\
\hline & $\begin{array}{l}\text { I want to continue to share my } \\
\text { personal information, because } \\
\text { Instagram stories help me build } \\
\text { social relationships with other } \\
\text { users. }\end{array}$ & 3,09 & & & \\
\hline & $\begin{array}{l}\text { I want to continue to share } \\
\text { information about myself because I }\end{array}$ & 2,19 & 3.00 & 0.72930 & 0,840 \\
\hline
\end{tabular}




\begin{tabular}{|l|l|l|l|l|}
\hline $\begin{array}{l}\text { Tie Strength } \\
\text { (TS) }\end{array}$ & $\begin{array}{l}\text { have a good relationship with other } \\
\text { users on Instagram stories. }\end{array}$ & \multirow{2}{*}{} & \\
\cline { 1 - 5 } & $\begin{array}{l}\text { I want to continue to share } \\
\text { information about myself because I } \\
\text { am close to other users on } \\
\text { Instagram stories. }\end{array}$ & 2,51 & & \\
\hline
\end{tabular}

This is the analysis of the factors that leading Instagram stories users to conduct public self-disclosure in order, starting from the highest to the lowest consider factors. First, the highest factor is the privacy concern (PC). Based on domicile, all cities such as Jakarta, Surabaya, Bandung, Medan, and Semarang have a high consideration of the privacy concern factor. This indicates that Instagram stories users in big cities have high attention to privacy issues; because according to 2018 criminal statistics data, those five big cities are included in areas that had high crime rates (BPS, 2018). Besides, based on gender, women have a higher consideration of the privacy concern factor when compared to men. This is because the majority of women who live in urban areas are often becoming victims of privacy violations. Moreover, according to research from UN Women Indonesia, $36.3 \%$ of women living in urban areas experienced more violence than $29.8 \%$ of women living in villages areas (Kumparan, 2018). Then based on age, Instagram stories users aged 18-21 years and 22-24 years have a high awareness of privacy issues.

Then the second dominant factor is perceived control (PCL). Users in all domiciles have a high consideration in this factor, which is caused by the easiness that Instagram stories provide through the privacy setting options such as close friends, block or hide stories. So, it implies that users in the five largest cities in Indonesia have high control over information that will be shared on Instagram stories. Based on gender, male users have higher control over information that will be shared on Instagram stories. By controlling their information, it means that male users will use Instagram stories less often than female users. Research from the Pew Internet Project also shows that male users use the internet less often for social media than female users (Zaenudin, 2018). Meanwhile, based on age, Instagram stories users aged 18-21 years and 22-24 years have high control over the information that will be shared on Instagram stories.

The third dominant factor is privacy awareness (PA), which the whole domicile also has a high consideration of this factor. It refers that users in metropolitan cities have awareness of the privacy options offered by Instagram. Because the presence of sophisticated technology facilities and adequate educational facilities in big cities makes it easier for users to understand the privacy options offered by Instagram stories. Then based on gender, male users are more aware of privacy options when compared to women. "The Browser Satiffactory Index" survey shows that male users are more interested in information related to technology (Zaenudin, 2018), and privacy options on Instagram stories are also part of the technology. Meanwhile, based on age, users in both categories (18-21 years and 22-24 years) have a high awareness of privacy options on Instagram. Because users at that age are included as digital natives who already technology literate, so 
they will find it easier to understand the options available on Instagram stories. Regarding the privacy awareness factor, researchers found that users of Instagram stories in Indonesia, both those who have public accounts or private accounts, are equally aware of one of the Instagram stories' privacy options, the "close friends" feature. But in reality, users are preferring to use "hide story" or "block" feature rather than the "close friends" feature.

The fourth dominant factor is tie strength (TS). In this factor, the whole domicile has a high consideration, which shows that users in the five major cities in Indonesia feel that they get the benefit when doing public self-disclosure as they can have personal ties with other Instagram stories users. Based on gender, men consider tie strength factor more than women. According to "Brandwatch", men use social media to gather the information that they need to build social networks (Vermeren, 2015). The activity of building social networks is a benefit that can be obtained by users when doing public self-disclosure as described in this factor. Then based on age, early adult users (22-24 years) feel more advantage on tie strength factors such as being able to build social relationships and maintain them as a social asset than late teenagers users (18-21 years). Because according to Hurlock (1999), someone who at the early adult category is included in reproductive age, so they try to find a suitable life partner through building social relationships.

Next, the fifth dominant factor is interaction (FINT). Jakarta City has the largest percentage of interaction factors, as evidenced by a statement from the Instagram press that Jakarta occupies the first ranks as the most often city that uses one of their interactive features namely location tags (Ewards, 2017). But other cities also have a high consideration of this factor, so it can be concluded that Instagram users in the 5 biggest cities in Indonesia feel the advantage when doing public self-disclosure such as being able to build social relationships through interacting with fellow users. Based on gender, male users consider FINT factor more than women. Just as previously explained that men use social media to build social networks, so they will feel a greater advantage when compared to female users. Meanwhile, based on age, early adult users (22-24 years) consider FINT factor more than late teenagers users (18-21 years). As explained earlier that users at this age are in the reproductive period and tend to be more actively interacting, to be able to build social relationships with other users.

The sixth dominant factor is a privacy risk (PR). The whole city has a high factor on the privacy risk factor, which shows that Instagram stories users in big cities have a high awareness of privacy risk that can be faced. This is following what the researchers have stated before, that the city of Jakarta, Surabaya, Bandung, Medan, and Semarang are included in an area that has a high crime rate (BPS, 2018). Based on gender, female users have a high awareness when compared to male users. Because as explained earlier that most women in urban areas have experienced privacy problems so they are more aware of the risks of privacy. Meanwhile, based on age, users aged 18-21 years and 22-24 years have a high consideration of privacy risk factors.

Last, the lowest consideration factor is privacy invasion experience (PIE), which is caused by the slight difference between agreeing and disagree answers 
from the respondent. Based on domicile, researchers found that Instagram stories users in Medan city had high consideration of PIE factors and preferred to reduce public self-disclosure activities with a frequency "once a month". This is consistent with the "Badan Pusat Statistik" data that the city of Medan in the North Sumatera province had the highest first crime rate in Indonesia in 2018 (BPS, 2018). While the cities of Jakarta, Surabaya, and Bandung did not consider PIE factors too much and chose to not reduce public self-disclosure activities, which can be seen through the tendency of users to conduct public self-disclosure with a frequency "several times a day". The city of Semarang does not have a certain tendency, because the frequency of public self-disclosure users has almost the same percentage for each option. Then based on gender, female users prefer not to reduce public selfdisclosure activities, as evidenced by the frequent frequency of opening. According to Andreassen, most social media users are dominated by women, which is caused by the tendency of addiction behaviour related to narcissism (Andreassen, Pallesen \& Griffths, 2017). Whereas based on age, users aged 18-24 years tend to not consider PIE factors and didn't want to reduce public self-disclosure activities.

Also, the researchers found that all factors had a high percentage of users who had a master's education background and professional education (had obtained a bachelor's degree and continued their education to add special expertise). So, it can be concluded that users who have higher education will consider more privacy factors before they do public self-disclosure. Because with the high literacy will make users more understand about privacy issues that can occur when they do public self-disclosure.

Then regarding the level of depth and breadth of public self-disclosure, researchers found that almost $50 \%$ of users were not too deep and broad in sharing their personal information on Instagram stories. But some other users have reached the deepest level of self-disclosure, which is caused by the desire to create a good self-image in front of another user even though the self-image is not necessarily the real self.

\section{CONCLUSION}

Based on the data and analysis, the researchers found that users of Instagram stories in the five largest cities in Indonesia conducted public self-disclosure by considering the following factors: perceived control (PCL), privacy awareness (PA), privacy concern (PC), privacy invasion experience (PIE), privacy risk (PR), interaction (FINT) and tie strength (TS). The privacy concern (PC) factor is the highest consideration factor for Instagram stories users in the 5 biggest cities in Indonesia. Because those five cities are included in the high crime rates area, which makes users more aware of privacy issues. While the lowest factor is privacy invasion experience (PIE) because some of Instagram stories users in Indonesia didn't agree to reduce public self-disclosure activities even though they have experienced privacy invasion problems.

The interesting thing found from this research is first, only Instagram stories users in Medan city have high consideration of the seven factors that cause users to do public self-disclosure, and they also have a very rare frequency of self- 
disclosure, which is only once a month. It can refer that Instagram stories users in Medan have high privacy awareness, so they prefer to reduce public self-disclosure activities. Second, female users more often do public self-disclosure compared to men, because women tend to have narcissistic attitudes. Third, users aged 18-24 are tech-savvy digital natives, so they understand the privacy options offered by Instagram. This result could be different if the selected respondents were not included in the digital natives' age. Fourth, users with higher education backgrounds such as master's education and professional education have high consideration in the seven factors that cause users to make public self-disclosure. So, this implies that the higher the level of education, the higher the user's awareness about privacy. Finally, researchers found that Instagram stories users in Indonesia are not too deep and broad when conducting public self-disclosure. So, it can be concluded that although Instagram stories users in the five largest cities in Indonesia have a very frequent frequency of public self-disclosure, they still process "what information" and "to whom" the information is shared as emphasized by Sandra Petronio in Communication Privacy Management Theory.

\section{BIODATA}

Shella Eunice Purmiasa, S.I.Kom is a Bachelor of Communication Science Dept on Petra Christian University, Jawa Timur, Surabaya, Indonesia.

Desi Yoanita, S.Sos.., M.Med.Kom is a lecturer of these following subjects: Interpersonal Communication, Family Communication, Basics of Journalism, News Gathering and Writing in Communication Science Dept, Petra Christian University, Surabaya, Indonesia since 2007.

Daniel Budiana, S.Sos., M.A. is a lecturer of TV Production, Advertising Production, and Communication Technology Development in Communication Science Dept, Petra Christian University, Surabaya, Indonesia since 2010.

\section{REFERENCES}

Ampong, G.O.A. et al. (2018). "Examining self-disclosure on social networking sites: A flow theory and privacy perspective". Journal of Behavioral Science, 8 (58), 29882801. doi: 10.3390/bs 8060058

Andreassen, C.S., Pallesen, S. \& Griffths, M. D. "The Relationship Between Addictive Use of Social Media, Narcissism, and Self-Esteem: Finding from a Large National Survey”. Journal of addictive behaviour 64 (2017): 03064603. Web 
Bazarova, N. N., Choi, Y. H. (2014). Self disclosure in social media: Extending the functional approach to disclosure motivations and characteristics on social networking sites. Journal Communication. 64, 635-657. Web

Bohang, F. K. (2018). Juni 2018, pengguna aktif Instagram tembus 1 miliar. Retrieved January 11, $2019 \quad$ from https://tekno.kompas.com/read/2018/06/21/10280037/juni-2018-penggunaaktif-instagram-tembus-1-miliar

BPS. (2018). Statistik kriminal 2018. Retrieved June 17, 2019 from https://www.bps.go.id/publication/download.html

Bungin, Burhan. (2006). Sosiologi komunikasi: Teori, paradigma, dan diskursus teknologi komunikasi di masyarakat. Jakarta: Prenada Media Group.

DeVito, J.A. (2005). Essentials of human communication $5^{\text {th }}$ edition. USA: Pearson Education, Inc.

Ewards, Ashton. (2017). The world's most popular locations on Instagram stories. Retrieved January 15, 2019 from https://fox13now.com/2017/08/09/theworlds-most-popular-locations-on-instagram-stories/

Gilbert, K. (2017). Biggest cities in Indonesia. Retrieved April 8, 2019 from https://www.worldatlas.com/articles/biggest-cities-in-indonesia.html

Goenawan, M. A. (2017). Orang Indonesia hobi bikin Instagram stories. Retrieved January 11, 2019 from https://inet.detik.com/cyberlife/d-3574532/orangindonesia-hobi-bikin-instagram-stories

Green, Leila. (2010). The Internet: An introduction to new media 2 nd edition. New York: Berk

Hurlock, E.B. (1999). Psikologi perkembangan: Suatu pendekatan sepanjang rentang kehidupan, Edisi kelima. Jakarta: Erlangga

Jeko. (2017). Orang Indonesia paling doyan main Instagram stories. Retrieved January 15, 2019 from https://www.liputan6.com/tekno/read/3037227/orangindonesia-paling-doyan-main-instagram-stories

Kriyantono, Rachmat. (2006). Teknik praktis riset komunikasi. Jakarta: Kharisma Putra Utama

Kumparan. (2018). Riset: 3 ribu perempuan Indonesia mengalami kekerasan di ruang publik. Retrieved June 21, 2019 from https://kumparan.com/@ kumparanstyle/riset-3-ribu-perempuan-indonesiamengalami-kekerasan-di-ruang-publik-1543220619019716868 
Mailanto, A. (2016). Pengguna Instagram di Indonesia terbanyak mencapai 89\%. $\begin{array}{llll}\text { Retrieved } & \text { February } & 2019 & \text { from }\end{array}$ https://techno.okezone.com/read/2016/01/14/207/1288332/penggunainstagram-di-indonesia-terbanyak-mencapai-89

Morrisan. (2013). Teori komunikasi:Individu hingga massa. Jakarta: Prenadamedia Group.

NapoleonCat. (2018). Instagram users in Indonesia. Retrieved February 23, 2019 from https://napoleoncat.com/stats/instagram-users-in-indonesia/2018/10

Nasrullah, R. (2015). Media sosial: Perspektif komunikasi, budaya, dan sosioteknologi. Bandung: Simbiosa Rekatama Media.

Sarwono, J. (2012). Metode riset skripsi pendekatan kuantitatif menggunakan prosedur spss: Tuntutan praktis dalam menyusun skripsi. Jakarta: PT. Elex Media Komputindo

Soehartono, Irawan. (2008). Metode penelitian sosial, suatu teknik penelitian bidang kesejahteraan sosial dan ilmu sosial lainnya. Bandung: Remaja Rosdakarya

Statista. (2019). Leading countries based on number of instagram user of 2019 (in millions). $\quad$ Retrieved February 21, 2019 from https://www.statista.com/statistics/578364/countries-with-most-instagramusers/

Vermeren, L. (2015). Men vs. women: Who is more active on social media. Retrieved June 21, 2019 from https://www.brandwatch.com/blog/men-vswomen-active-social-mediap

West, R \& Turner, L.H. (2014). Pengantar teori komunikasi: analisis dan aplikasi. Jakarta: Salemba Humanika

Zaenudin, Ahmad. (2018). Beda perilaku laki-laki dan perempuan dalam menggunakan internet. Retrieved June 21, 2018 from https://tirto.id/bedaperilaku-laki-laki-dan-perempuan-dalam-menggunakan-internet-cEWT 